\title{
HYDRODYNAMIC ASPECTS OF BLADDER-OUTLET OBSTRUCTION: CONSEQUENCES OF FUNCTIONAL MICTURITION DISORDERS
}

\author{
By H. Madersbacher, H. Marberger and G. Holl \\ Department of Urology, University Hospitals, Innsbruck, Institute of Hydraulics, Technical \\ University Graz and Rehabilitation-Centre Bad Häring, Austria
}

\begin{abstract}
Functional disturbances of micturition lead to secondary structural changes. Both factors may change the physical properties-shape, elasticity and consistency-of the posterior urethra and of the bladder neck. In order to demonstrate their influence on urodynamics experimental studies were undertaken, elastic models, straight tubes of equal diameter throughout their length, were used. One model was a straight elastic tube of PVC material, three other models had nonelastic segments of different shape but with the same square area as the undeformed elastic parts. Perfusion was performed under equal conditions.

The experiments showed firstly that nonelastic segments in an elastic system reduce the flow rate and secondly, that flow depends on cross section versus circumference, which is expressed by the so-called hydraulic diameter.

Elasticity, consistency and shape of the bladder-outlet, frequently altered in patients with neurogenic bladder disease, are therefore important factors regarding loss of friction. Our results support the clinical experience, that a functional obstruction has to be eliminated before secondary structural changes occur which alter the physical properties of the bladder outlet and therefore make flow conditions even worse.
\end{abstract}

Key words: Functional bladder outlet obstruction; Elastic urethral models; Urodynamics.

\section{Introduction}

BLADDER, posterior urethra and pelvic floor are functionally one unit: simultaneously with the detrusor contraction the bladder outlet opens and shapes up to a streamlined funnel, which provides the best urodynamic conditions for a quick expulsion of urine. At least this is the case with the healthy man.

On the other side comparatively little changes at the bladder outlet, varying size, shape and surface of the posterior urethra may influence drastically the normal urodynamics, as we could show in previous experiments: the influence of the shape of the bladder outlet or the increase of resistance to flow due to the roughness of the surface was a particularly striking experience (Marberger, 1963; Marberger \& Madersbacher, 1969; Marberger et al., 1973).

Neurogenic bladder disorders may change urodynamics in many ways: there are firstly functional disturbances of micturition, like detrusor-sphincterdyssynergia or functional obstruction as observed with passive voiding by straining or Credé, and then, as a consequence of these dysfunctions, secondary morphologic changes. Chronic prostatitis, caused by overpressure, mechanical and chemical irritation and lastly by true infection, is such a consequence and therefore a common disease in paraplegics, the frequency of which is steadily rising with the course of the years (Madersbacher, I977): our analysis of I43 patients showed, that after 15 years of paraplegia the percentage of patients with prostatitis, documen- 
ted by reflux into the male adnexa, by prostatic stones or caverns, goes up to 85 per cent. Both factors, the dysfunction itself as well as its morphologic consequences are changing the shape, the elasticity and the consistency of the bladder outlet.

In the following experiments the influence of the urethral contour as seen in a transversal section, as well as the influence of changes in elasticity and consistency on the flow rate are demonstrated.

\section{Experimental Conditions}

Elastic models, straight tubes of equal diameter, made of PVC-material, were used. Flow conditions were studied in four different tubes (see Fig. I): Model I is a straight elastic tube with constant diameter throughout its length; Model II is a straight elastic tube with a circular nonelastic section of the same diameter as the undeformed elastic tube. Such a model may remind you of the contour of a neuropathic urethra as it is seen on voiding cystourethrograms of a reflex micturition with a ring-like segment at the level of the pelvic floor (see Fig. 2) with certainly higher consistency and altered elasticity. Model III (see Fig. 3a) is a straight elastic tube with a half moon configuration of the non-elastic section whose free area of flow is of the same size as the one of the undeformed elastic tube; this configuration can be observed in patients with prostatitis and rigid unelastic walls.

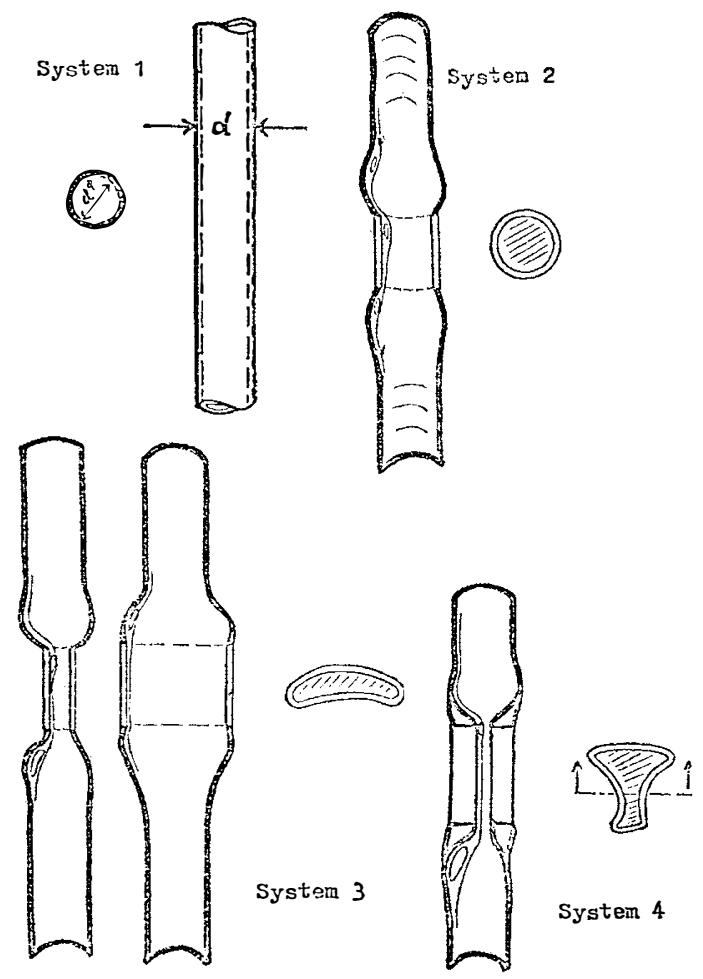

FIG. I

Models which were perfused on equal conditions. For explanations see text. 


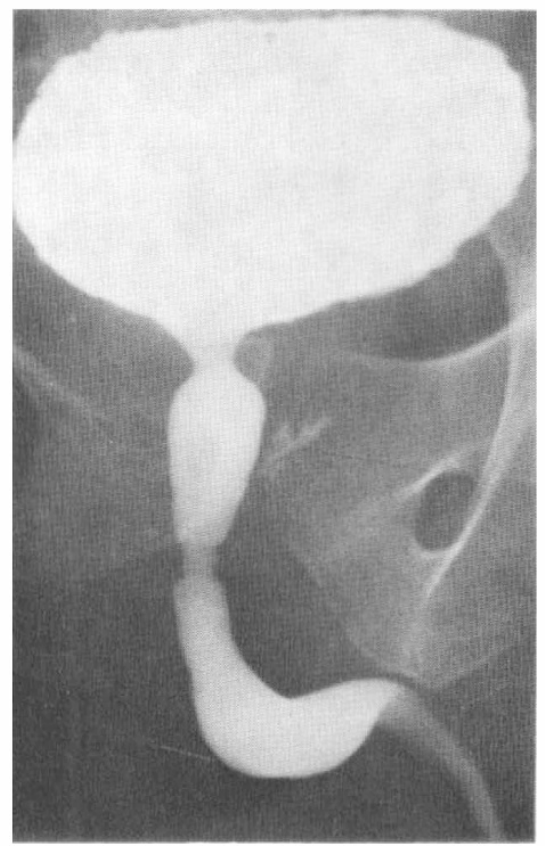

FIG. 2

Voiding cystourethrogram-reflex bladder. Bandlike narrowing of the membranous urethra at the level of the pelvic floor due to detrusor-sphincter-externus-dyssynergia with certainly higher consistency and altered elasticity; amphora-like dilatation of the posterior urethra, reflux into the adnexa, no funnelling of the bladder neck.

Model IV (see Fig. 3b) is a straight elastic tube with a T-bar-like deformed nonelastic section, again with the same square-area as the undeformed elastic tube. This T-bar-like configuration, for example, is very similar to the urethral deformation after 12 o'clock sphincterotomy as it was demonstrated previously in this journal (Madersbacher, 1976, Fig. 3) on an endoscopic photo, showing the contour of the posterior urethra as seen from the bulbous urethra I year after an anteromedian sphincterotomy.
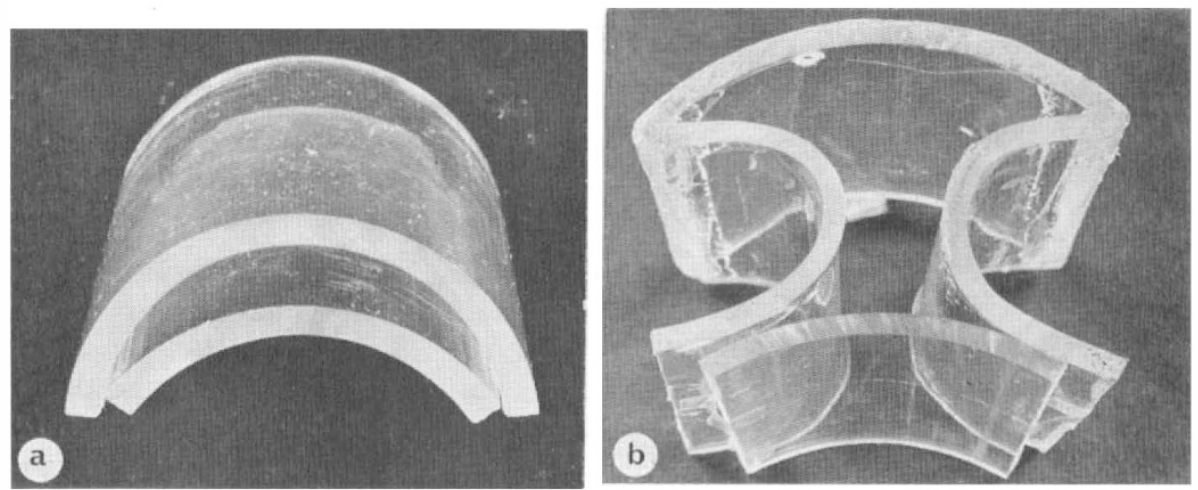

FIG. 3

Shape of unelastic sections in model III $(a)$ and model IV $(b)$. For explanations see text. 
The idea was to simulate flow conditions under normal and pathological conditions in the posterior urethra, represented by an elastic tube. The models simulate different pathological conditions like loss of elasticity as in model II or loss of elasticity together with change of contour as in models III and IV.

\section{Model I}

\section{Results}

Here, a loss of friction can be observed which is measured by well-known friction coefficients of rigid tubes.

\section{Model II}

There is a clearly formed ballooning at the entrance as well as at the exit of the unelastic line section when perfused; further loss of friction in the ballooning parts of the tube are added to the loss of friction mentioned above. Due to the rapid widening of the free diameter of flow in the ballooned parts of the tube, a separation of flow at the walls is developed and a dead water zone with the walls is formed, thus the loss of flow is drastically increased.

\section{Model III}

The created loss of friction increases due to the fact that the hydraulic diameter $\left(D_{h}\right)$ relevant for measuring the loss of frictions is considerably smaller.

$$
\left(D_{h}=\frac{4 F}{U} ; F=\text { square area of flow, } U=\right.\text { wetted perimeter of the tube ). }
$$

As the diameter is quickly widened a separation of flow is also developed with this system as in model II. It occurs with ballooning in the direct transition area between the elastic and nonelastic tube.

Model IV: with this diameter form of the nonelastic section, the loss of friction will further increase. The definition of a hydraulic diameter as in model III loses its validity as the flow in the extremely narrow side canals becomes significantly slower in relation to the central main flow; the flow in the narrow marginal areas can change from tubular to laminar. The loss of friction at the entrance and exit of the grossly deformed nonelastic section is remarkably high with this system, as further losses due to the largely varying speed of flow in the narrow side canals of the nonelastic sections are added to losses caused by a separation of flow due to the rapid widening of the diameter. The varying speed of flow leads to a different energetic capacity of the individual particles and causes losses when being mixed.

\section{Discussion}

The experiments showed firstly that unelastic areas in an elastic system will reduce the flowrate considerably (see Fig. 4) and secondly that flow depends on the cross-section versus circumference, which is expressed by the hydraulic diameter $\left(D_{h}\right)$. We therefore found an increase in resistance paralleling the increase of the circumference and the number and size of dentations in the models.

The experiments support the clinical experience, that size and volume of the prostate are by far not the only factors which determine the flow. They support 


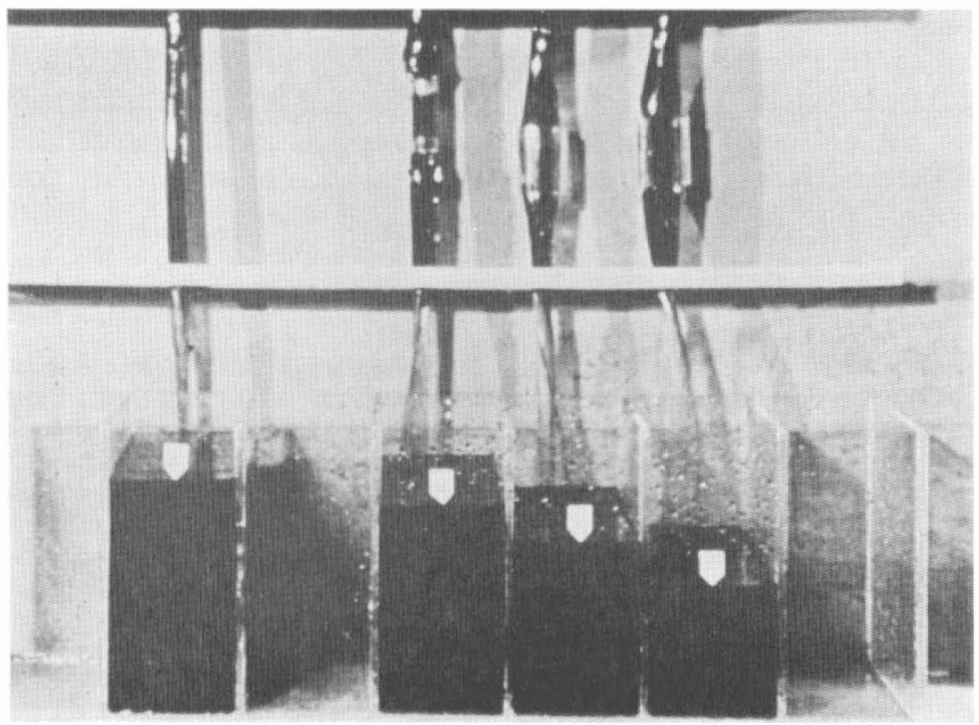

Fig. 4

Hydrodynamic consequences of the perfused models due to different shape, consistency and elasticity, made visible by the flow rates of the four models.

our clinical experience and explain why changes of the physical properties of the wall of the bladder outlet alone can decrease the flow rate considerably. Elasticity, consistency and shape, frequently altered in patients with neurogenic bladder disease, are therefore important factors causing loss of friction, decrease of flow and an increase of outflow resistance with all its consequences to the detrusor muscle.

\section{Conclusions}

It is evident from these experiments that a functional obstruction has to be eliminated before secondary morphologic changes occur with all its consequences on micturition. In an early state a minimal transurethral operation like it is the anteromedian incision of the so-called external sphincter (Madersbacher \& Scott, 1976; Whitmore et al., 1978), which is able to better the situation drastically. Later in the course of the disease it is sometimes very difficult to better bladder emptying even by major transurethral surgery due to the meanwhile established changes of the physical properties of the bladder outlet.

\section{SUMMARY}

Neurogenic bladder disorders may change the urodynamics of the bladder outlet in many ways, primarily by functional disturbances like detrusor-sphincterdyssynergia and then, as consequence of them, by secondary structural changes.

In order to demonstrate the influence on flow and resistance, perfusion experiments were undertaken, using elastic tubes with nonelastic segments of different shape, thus simulating different pathological conditions of the posterior urethra. 
The results obtained demonstrated that elasticity, consistency and shape of the bladder outlet, frequently altered in patients with neurogenic bladder disease, are important factors causing loss of friction, decrease of flow and increase of outflow resistance. This stresses the importance that a functional obstruction has to be eliminated before irreversible structural changes, with all its further consequences to urodynamics, occur.

\section{RÉSUMÉ}

Certaines perturbations neurogéniques de l'évacuation de la vessie conduisent, pour plusieurs raisons, à des modifications de l'urodynamique à l'évacuation; d'abord c'est le dérèglement fonctionnel en tout que tel, comme par exemple la dyssynergie du sphincter et du détruseur, qui a pour conséquences des altérations structurelles secondaires.

Pour démonstrer son influence sur le débit de l'urine et sur la résistance à l'évacuation, on a procédé à des expériences de passages de liquide; on s'est servi comme modèles de tuyaux élastiques avec segments non-élastiques de formes variées. Les parties élastiques et les non-élastiques avaient la même coupe, et le parcours de liquide se faisait dans les mêmes conditions. Les différents modèles symbolisaient différents états pathologiques de l'urètre postérieur.

Les résultats montrent, que l'élasticité, la consistance et la forme du système d'évacuation, qui sont souvent modifiées, précisément chez des patients souffrant de perturbations urinaires neurogènes, présentent des facteurs importants qui conduisent à baisse de la dynamique par frottement, à un débit d'urine défectueux et à une augmentation de résistance à l'expulsion. Les résultats expérimentaux font ressortir l'expérience clinique, à savoir qu'une obstruction fonctionnelle devrait être enlevée avant qu'elle ne conduise à des altérations structurelles irréversibles, qui à leur tour, en raison de la modification de l'élasticité, de la consistance et de la forme conduisent à une altération secondaire de l'évacuation urinaire.

\section{ZUSAMMENFASSUNG}

Neurogene Blasenentleerungsstörungen führen aus mehreren Gründen zu Veränderungen der Urodynamik am Blasenauslaß; zunächst ist es die funktionelle Störung als solche, wie etwa die Detrusor-Sphinkter-Dyssynergie, die im weiteren zu sekundären strukturellen Veränderungen führen.

Um ihren Einfluß auf den Harnfluß und den Ausflußwiderstand zu zeigen, wurden Durchströmungsexperimente durchgeführt. Als Modelle dienten elastische Rohre mit unelastischen Segmenten verschiedener Form, wobei die elastischen und unelastischen Teile denselben Querschnitt hatten und unter gleichen Bedingungen durchströmt wurden. Verschiedene Modelle symbolisierten verschiedene pathologische Zustände der hinteren Harnröhre.

Die Ergebnisse zeigen, daß Elastizität, Konsistenz und Form des Blasenauslasses, die häufig gerade bei Patienten mit neurogenen Blasenstörungen verändert sind, wichtige Faktoren darstellen, die zu Reibungsverlusten, zu schlechtem Harnfluß und $\mathrm{zu}$ einem erhöhten Austreibungswiderstand führen.

Diese experimentellen Ergebnisse unterstreichen die klinische Erfahrung, daß eine funktionelle Obstruktion beseitigt werden sollte, bevor sie zu irreversiblen strukturellen Veränderungen führt, die ihrerseits auf Grund der veränderten Elastizität, Konsistenz und Form zu einer weiteren Verschlechterung der Blasenentleerung führen.

\section{REFERENCES}

MADERSBACHER, H. \& SCOTt, F. B. (1976). The I2 o'clock sphincterotomy: technique, indications, results. Paraplegia, 13, 26I-267.

MADERSBACHER, H. (1977). Urethrogram and pathophysiologic aspects. Eur. Urol., 3, $32 \mathrm{I}-332$.

MARBERGER, H. (1963). Bladder neck obstruction in childhood. Acta urol. belg., 3I, 492.

MARBERGER, H. \& MADERSBACHER, H. (I969). Beobachtungen über die Störungsverhältnisse am Blasenhals. Verh. dt. Ges. f. Urologie, 22. Tag., pp. I00-104, Springer: Berlin. 
Marberger, H., Madersbacher, H. \& Swoboda, H. P. (I973). Motion picture: energy destroyer in urology. In Urodynamics, pp. 23-25, Springer: Berlin.

WhitmoRe, W. F. III, FAM, B. A. \& Yalla, S. V. (I978). Experience with Anteromedian (I2 o'clock) external urethral sphincterotomy in IOO male subjects with neuropathic bladders. Brit. F. Urol., 50, 99-IOI. 